\title{
THE EFFECTIVENESS OF USING PHOTOGRAPHS ON TEACHING WRITING NARRATIVE TEXT FOR NON-ENGLISH DEPARTMENT STUDENTS
}

\section{FITRANA HARINTAMA}

Universitas Islam Negeri Malang

Email: harintama@gmail.com

\begin{abstract}
This study concerns about teaching writing, especially writing narrative text by using picture prompts as media. Picture prompts are believed can make the students relax to study and can encourage them to begin to write. Picture prompts have many advantages in teaching and learning writing. Related to the objective of the study, the aim of this study is to find whether picture prompts can help the students to get higher scores or not. This research will be done in UIN Maulana Malik Ibrahim Malang in Arabic Language and Literature Department with the research object of class $A$ for experimental group and class $B$ for control group. The objective of the study is to investigate the effectiveness of using picture prompts in writing class in helping students write narrative texts. The quasi-experimental research design will be used in writing this research. This research design was chosen because it was impossible for the researcher to randomize the subjects to the intended conditions. This was due to the fact that moving the students from one class to another in order to get the ideal groups for the sake of the experiment was not allowed. As the study deals with the students of two different classes, the explanation about teaching-learning processes will be applied to it. In the processes, the researcher will conduct pretest to know the students' writing ability before getting treatment of writing narrative using picture prompts. After the treatment, the researcher conducts posttest to compare the result and to discover whether the students get higher score or not. Then the results of the research between two subjects will be analyzed using SPSS (Statistical Package for The Social Science) data analysis of group pair data.
\end{abstract}

Keywords: Picture Prompts, Narrative Text, Writing

\section{Introduction}

Writing is the most complicated skill compared to other four skills, even for native speakers. The basic problem of writing is to find and explore the right ideas. Generating ideas is crucial to the success of any writing but seldom given attention by the writers ${ }^{1}$. That is why teachers need an appropriate method to stimulate the students' ideas based on their knowledge and age.

Writing for the students holds the key role to develop their thoughts and ideas. Writing could be a powerful instrument of thinking because it provides students with a way of gaining control over their thoughts. This is because when the students try to write about

\footnotetext{
${ }^{1}$ Bearne, E. 1998. Making Progress in English. London: Routledge.
} 
their ideas, they also start to think about how to deliver their ideas to the readers ${ }^{2}$. Writing is creative process because in this phase, students must know what they are writing about and can organize it reasonably and persuasively in a fundamental sense.

To know the ability of the students in writing is to get them to write ${ }^{3}$. As teachers, we must give instructions to the students about what they should write and how to write and evaluate their writing products ${ }^{4}$. Teachers should realize that they need to be the model, provide real purpose and real audience for the students. Another role of the teacher is providing media for the students. As teacher, when selecting a medium for teaching, the teachers should consider its appropriateness for the particular content or activity. Images and photographs can be good teaching media because images communicate everything at once ${ }^{5}$. Images also offer immediacy and they capture the entirety of a view, have ability to convey emotion and feeling more directly than text can, they do not require decoding because they convey information literally.

Using digital images as instructional teaching media is more flexible than the printed one because the content can be stored and presented in any medium and quickly transferred from one medium to another.

In teaching and learning writing activity, teachers focus on both the content and the form of the writing, which is the language used, the text structure, the construction of the idea, grammar and punctuation?. Besides, teachers also focus on vocabulary, spelling, mechanics, and organization.

Based on the findings of the observation in the PKPBI classes, the researcher found out that teaching writing using photographs has not been implemented yet and most of the students in the classes have difficulties in writing especially in the micro skills of writing such as: vocabulary, grammar; taking information and/or ideas from another writer and using them in his/her own work without acknowledging the source in an accepted manner and the tendency to do plagiarism ${ }^{8}$, punctuation, mechanics, and the genre/text type itself.

\footnotetext{
${ }^{2}$ Gere, A.R. 1985. Writing and Learning. New York: Macmillan Publishing Company.

${ }^{3}$ Gere, A.R. 1985. Writing and Learning. New York: Macmillan Publishing Company.

${ }^{4}$ Weigle, S.C. 2002. Assessing Writing. Cambridge University Press

${ }^{5}$ Rose, D. H., Meyer, Anne.,Strangman, Nicole., and Rappolt, Gabrielle. 2002. Teaching Every Student in the Digital Age Universal Design for Learning. Alexandria, Virginia: ASCD.

${ }^{6}$ Rose, D. H., Meyer, Anne.,Strangman, Nicole., and Rappolt, Gabrielle. 2002. Teaching Every Student in the Digital Age Universal Design for Learning. Alexandria, Virginia: ASCD.

${ }^{7}$ Coffin, C., Curry, M. J., Goodman, S., Hewings, A., Lillis, T. M., and Swann, J. 2003. Teaching Academic Writing. A Toolkit for Higher Education. London: Routledge.

${ }^{8}$ Bailey, Stephen. 2006. Academic Writing. A Handbook for International Students. Second Edition. Madison Ave: Routledge.
} 
PKPBI is a program of English course in State Islamic University of Maulana Malik Ibrahim Malang for the students of all departments (except English Department) of third and fourth semesters. PKPBI stands for Program Khusus Pengembangan Bahasa Inggris which has function to provide students with the programs of English for Specific Purposes. The course of PKPBI is divided into two different types; they are regular and intensive classes. Regular class has responsible to teach the students writing and reading skills while intensive class brings the students to study speaking and listening skills.

In regular classes most of the students of PKPBI course still get confused in writing activity which starts from the planning stage. The students found it hard to gather ideas to begin to write. The students usually get confused how to start writing even though they are already told the type of writing they should write.

From these problems, the researcher thinks that the students need a better strategy in teaching writing. The students need a strategy which can influence and improve their ability in writing to follow the sequence, to write in a proper grammatical order, to avoid plagiarism, pay attention to punctuation, mechanics, and the genre. The proposed strategy in this research is using pictures to write narrative text since this text type is taught in the odd semester. The pictures are shown to the students by LCD Projector.

In addition, Seow suggests the process of writing into stages as planning (pre-writing), drafting (writing), revising (redrafting), and editing. The step planning or thinking involves choosing the ideas, exploring ways of developing the ideas, and devising strategies of organization and style.

Pictures, and especially photographs, carry with them implicit narratives, making them ideal writing prompts for generating new short story ideas ${ }^{10}$.

In this research, the students are guided to write narrative text by using photographs. The purpose of narrative text is to amuse and entertain the readers. Narrative text helps the students to express themselves creatively and imaginatively. In this research, the students are required to make interactive combination of narrative text and photographs, even sound.

${ }^{9}$ Seow,Anthony. 2002. The writing Process and Process Writing. In Richard and Renandya (Ed.), Methodology in Language Teaching: An Onthology of Current Practice (pp. 315-320). New York: Cambridge University Press.

${ }^{10}$ Wiehardt, $\quad 2010 . \quad$ Photograpghs as Writing Prompts. http://fictionwriting.about.com/od/writingexercises/ht/gettingideas.htm 


\section{Research Design}

This research uses quasi-experimental research design. As stated in Chapter I, the problem of this research is to analyze whether there is any difference in achievement in students' writing taught by using photographs than those taught using picture series. Photographs are chosen instead of picture series because it is expected to be able to increase the students' imagination. Moreover, students are not glued to the sequences provided as in the picture series.

This research design is chosen because it is impossible for the researcher to randomize the subjects to the intended conditions. This was due to the fact that moving the students from one class to another in order to get the ideal groups for the sake of the experiment was not allowed. When the researcher conducts educational research, it is not always possible to select or assigned subjects at random ${ }^{11}$. Therefore, class A and class B of the PKPBI regular classes of the Arabic Language and Literature of State Islamic University of Maulana Malik Ibrahim Malang (UIN Malang) batch 2012, were taken as the subjects of this research because the researcher teaches those students and already knows the condition of the class. The research design used was pretest-posttest, nonequivalent control group design. An important component of the quasi-experimental study is the use of pretesting or analysis of prior achievement to establish group equivalence ${ }^{12}$. The research design can be diagrammed as follows:

\begin{tabular}{|cccl|}
\hline Groups & Pretest & Treatment & Posttest \\
C & $\mathrm{P}$ & $\mathrm{Y}$ & $\mathrm{O}$ \\
$\mathrm{E}$ & $\mathrm{P}$ & $\mathrm{X}$ & $\mathrm{O}$ \\
\hline
\end{tabular}

The codes used in the diagram above illustrate the following:

C represents the control group (class A)

E represents the experimental group (class B)

$P$ represents the pretest

O represents the posttest

Y represents the students' story starters to the control group

$\mathrm{X}$ represents the students' photographs to the experimental group

\footnotetext{
${ }^{11}$ Wiersma, William. 1991. Research Methods in Education. Needham Heights, MA: Allyn and Bacon.

12 Ross M. S and Morrison G. R. 2001. Experimental Research Methods. Bloomington, Indiana: AECT.
} 
At the beginning of experimentation, the subjects in both control and experimental groups were tested to examine the initial mastery of the subjects' writing competence prior to the treatment. After that, the experimental group was exposed to the students' photographs approach in the writing class while the control group underwent a teaching process using story starters. Finally, after the experimentation, the students' mastery on writing was measured. The test employed in the posttest was the one used in the pretest. Eventually, the scores obtained by both control and experimental groups from the posttest were compared using the pretest scores to investigate the effect of the treatment on the students' writing competence.

\section{Research Procedures}

During the experiment, the two groups experienced different treatments. The $\mathrm{E}$ group is taught by using photographs, while the $\mathrm{C}$ group is taught by using story starters. The teaching and learning process experienced by both groups was scheduled based on the basic course outline. Planning is a step to prepare the classroom instructional strategy to be developed in the study to solve the instructional problems ${ }^{13}$. The research takes eight meetings consist of pretest, six treatments and posttest. Week one was scheduled for pre-test which has function to monitor the students' ability before the treatment conducted. Week two were for the input session in which the theories of narrative text which covered: generic structures of narrative text: orientation, complication, resolution, and reorientation; language features: past tenses, the photographs (E) and the story starters (C) and the examples of narrative texts were presented.

In the third week, the students are taught to write their first draft in which the $\mathrm{E}$ group learned writing by using the photographs (Appendix 1), while the students of C group experienced a teaching process implementing the story starters. After finishing the first draft, the both groups were required to reread their own drafts. The lecturer supervised in order to make sure they know their mistakes and how to revise it. In the following week (week three), based on the self-evaluation made, the students were required to revise their first drafts. The drafts produced after the revision were then read by the lecturer in order that she could give general comments on the drafts for further revision. The comments covered all aspects of writing but they were not directed to individual student. The drafts were then taken by the

${ }^{13}$ Latief, Mohammad Adnan. 2012. Research Methods on Language Learning: An Introduction. Malang: UniversitasNegeri Malang. 
lecturer for lecturer's feedback. The lecturer gave written comments on each essay. In the next week until seventh meeting the treatments will be repeated. In eighth week, the students produced the final version of their essay, the feedback as well. The details of the steps which are through by the students are presented in the lesson plan (Appendix 2).

During the treatment, both students in the $\mathbf{E}$ group and $\mathbf{C}$ group were not allowed to take their writings home to minimize the invalidity of the research. Students are cheating more often today with sophisticated cheating technique because it is easier, especially with the new technologies ${ }^{14}$. To avoid the plagiarism, the researcher could check the writing product using ed.gramarly.com. Beside the plagiarism issue, allowing the students to take their assignments home would trigger some other invalidity for example the students might ask other people to help them do the assignment or use Google translate and they might ask other people to give them feedback for their writing. If the students are not proficient with the language instruction, they will probably translate into the language they understand. But that the translations by Google Translate needed substantial improvement in their quality. Nevertheless, the quality was still below average, and the texts would require extensive postediting for their function to be met ${ }^{15}$.

In the eighth week, the researcher holds posttest to calculate and compare the scores obtained between pretest and posttest. Posttest is held in order to know whether the treatment gave the significant influence in students writing or not.

The teaching writing narrative text using photographs is considered successful if the students can write narrative text using correct grammar of present tense and past tense, can write using correct punctuation, spelling and mechanics, and also can write narrative text without doing plagiarism in terms of the content.

\section{Data Collection Techniques}

After the treatment was over, a post-test was conducted to measure the achievement of both groups. The scores obtained from the post-test were then used as the dependent variable in the statistical calculation. The data in this study were obtained from pre-test and post-test scores of both control and experimental groups. For pre-test, the researcher asks the students to write recount text of their last holidays while in the post-test, the students are

\footnotetext{
${ }^{14}$ Lathrop, Ann and Foss, Kathleen. 2000. Student Cheating and Plagiarism in the Internet Era: A Wake-up Call. Englewood, Colorado: Greenwood Publishing Group, Inc.

${ }^{15}$ Rensburg, A., Snyman, C., and Lotz, S. 2012. Applying Google Translate in a Higher Education Environment: Translation Product Assessed. In article compilation entitled Southern African Linguistics and Applied Language Studies. NISC (Pty) Ltd.
} 
asked to write about their unforgettable experiences. Both groups are given the same tests at the same time. Language testing is a precise tool or systematic procedure to measure some samples of students' language competence in studying language ${ }^{16}$.

\section{Data Analysis Techniques}

After collecting the data of pretest and posttest from the experimental group and control group, then the researcher measured the score differences from pretests and posttests of the experimental group and control group by using statistical calculation. Analysis of data includes comparison of the outcomes of the treatments upon the both groups and the making of a decision as to the achievement of the goals of research ${ }^{17}$. In this study, the researcher used repeated measures t-test to find out whether the differences between them were significant. T-test is used to measure and compare the difference of means score between experimental group and control group ${ }^{18}$. The researcher chooses repeated measures t-test or paired t-test because this research design is pretest-posttest design which each subject has pretest score and after intervention of treatments, the subjects then given posttest. The use of repeated measures t-test is also suitable because each group is given different treatment $^{19}$. If the result shows that both writing abilities are not equal, ANCOVA (Analysis of Covariance) will be used in the final analysis. The using of t-test in this research is based on some assumptions; they are the homogeneity of variances, independence of covariates and treatment effect, homogeneity of regression slopes and this research compares means of two groups.

To calculate the differences between two subjects, the researcher uses SPSS (Statistical Package for the Social Science). SPSS is one of the most commonly used statistical packages in the social science ${ }^{20}$. The SPSS data analysis technique which is used is group of paired data to calculate the differences of each subject of experimental and control group after treatments. To find out the differences of both groups, the researcher must calculate the difference due to treatment for each individual.

\footnotetext{
${ }^{16}$ Saukah, Ali. 2013. Penilaian Pembelajaran Bahasa. Malang: UM Press.

${ }^{17}$ Singh, Yogesh Kumar. 2006. Fundamental of Research Methodology and Statistics. Daryaganj, New Delhi: New Age International.

18 Arikunto, Suharsimi. 2006. ProsedurPenelitianSuatuPendekatanPraktik. Jakarta: RinekaCipta.

${ }^{19}$ Setiyadi, Bambang. 2006. MetodePenelitianUntukPengajaranBahasaAsing: PendekatanKuantitatifdanKualitatif. Yogyakarta: GrahaIlmu.

${ }^{20}$ Balnaves, Mark and Caputi, Peter. 2001. Introduction to Quantitative Research Methods: An Investigative Approach. Thousand Oaks, CA: SAGE.
} 


\section{References}

Arikunto, Suharsimi. 2006. Prosedur Penelitian Suatu Pendekatan Praktik. Jakarta: Rineka Cipta.

Bailey, Stephen. 2006. Academic Writing. A Handbook for International Students. Second Edition. Madison Ave: Routledge.

Balnaves, Mark and Caputi, Peter. 2001. Introduction to Quantitative Research Methods: An Investigative Approach. Thousand Oaks, CA: SAGE.

Coffin, C., Curry, M. J., Goodman, S., Hewings, A., Lillis, T. M., and Swann, J. 2003. Teaching Academic Writing. A Toolkit for Higher Education. London: Routledge.

Gere, A.R. 1985. Writing and Learning. New York: Macmillan Publishing Company.

Lathrop, Ann and Foss, Kathleen. 2000. Student Cheating and Plagiarism in the Internet Era: A Wake-up Call. Englewood, Colorado: Greenwood Publishing Group, Inc.

Latief, Mohammad Adnan. 2012. Research Methods on Language Learning: An Introduction. Malang: UniversitasNegeri Malang.

McMillan, James. H. 1992. Educational Research. Fundamentals for The Consumer. Virginia Commonwealth University: HarperCollinsPublishers.

Rensburg, A., Snyman, C., and Lotz, S. 2012. Applying Google Translate in a Higher Education Environment: Translation Product Assessed. In article compilation entitled Southern African Linguistics and Applied Language Studies. NISC (Pty) Ltd.

Rose, D. H., Meyer, Anne., Strangman, Nicole., and Rappolt, Gabrielle. 2002. Teaching Every Student in the Digital Age Universal Design for Learning. Alexandria, Virginia: ASCD.

Ross M. S and Morrison G. R. 2001. Experimental Research Methods. Bloomington, Indiana: AECT.

Saukah, Ali. 2013. Penilaian Pembelajaran Bahasa. Malang: UM Press.

Seow,Anthony. 2002. The writing Process and Process Writing. In Richard and Renandya (Ed.), Methodology in Language Teaching: An Onthology of Current Practice (pp. 315-320). New York: Cambridge University Press.

Setiyadi, Bambang. 2006. Metode Penelitian Untuk Pengajaran Bahasa Asing: Pendekatan Kuantitatif dan Kualitatif. Yogyakarta: Graha Ilmu.

Singh, Yogesh Kumar. 2006. Fundamental of Research Methodology and Statistics.Daryaganj, New Delhi: New Age International.

Weigle, S.C. 2002. Assessing Writing. Cambridge University Press 
Fitrana Harintama, The Effectiveness of Using Photographs on Teaching Writing Narrative Text for Non-English Department Students

Wiehardt, Ginny. 2010. Photograpghs as Writing Prompts. http://fictionwriting.about.com/od/writingexercises/ht/gettingideas.htm

Wiersma, William. 1991. Research Methods in Education. Needham Heights, MA: Allyn and Bacon. 